\title{
STUDIES IN ECONOMIC AND SOCIAL HISTORY
}

This series, specially commissioned by the Economic History Society, provides a guide to the current interpretations of the key themes of economic and social history in which advances have recently been made or in which there has been significant debate.

Originally entitled 'Studies in Economic History', in 1974 the series had its scope extended to include topics in social history, and the new series title, 'Studies in Economic and Social History', signalises this development.

The series gives readers access to the best work done, helps them to draw their own conclusions in major fields of study, and by means of the critical bibliography in each book guides them in the selection of further reading. The aim is to provide a springboard to further work rather than a set of pre-packaged conclusions or short-cuts.

\section{ECONOMIC HISTORY SOCIETY}

The Economic History Society, which numbers over 3000 members, publishes the Economic History Review four times a year (free to members) and holds an annual conference. Enquiries about membership should be addressed to the Assistant Secretary, Economic History Society, Peterhouse, Cambridge. Full-time students may join at special rates. 


\title{
STUDIES IN ECONOMIC AND SOCIAL HISTORY
}

\author{
Edited for the Economic History Society by T. C. Smout
}

PUBLISHED

Bill Albert Latin America and the World Economy from Independence to 1930 B. W. E. Alford Depression and Recovery? British Economic Growth, 1918-1939

Michael Anderson Approaches to the History of the Western Family, 1500-1914

P. J. Cain Economic Foundations of British Overseas Expansion, 1815-1914

S. D. Chapman The Cotton Industry in the Industrial Revolution Neil Charlesworth British Rule and the Indian Economy, 1800-1914

J. A. Chartres Internal Trade in England, 1500-1700

R. A. Church The Great Victorian Boom, 1850-1873

D. C. Coleman Industry in Tudor and Stuart England

P. L. Cottrell British Overseas Investment in the Nineteenth Century Ralph Davis English Overseas Trade, 1500-1700

M. E. Falkus The Industrialisation of Russia, 1700-1914

Peter Fearon The Origins and Nature of the Great Slump, 1929-1932

$T$. R. Gourvish Railways and the British Economy, 1830-1914

Robert Gray The Aristocracy of Labour in Nineteenth-century Britain, 1850-1900

John Hatcher Plague, Population and the English Economy, 1348-1530

$J$. R. Hay The Origins of the Liberal Welfare Reforms, 1906-1914

R. H. Hilton The Decline of Serfdom in Medieval England

E. L. Jones The Development of English Agriculture, 1815-1873 John Lovell British Trade Unions, 1875-1933 J. D. Marshall The Old Poor Law, 1795-1834

Alan S. Milward The Economic Effects of the Two World Wars on Britain G. E. Mingay Enclosure and the Small Farmer in the Age of the Industrial Revolution Rosalind Mitchison British Population Change Since 1860 R. J. Morris Class and Class Consciousness in the Industrial Revolution,

$1780-1850$

A. E. Musson British Trade Unions, 1800-1875

R. B. Outhwaite Inflation in Tudor and Early Stuart England $R$. J. Overy The Nazi Economic Recovery, 1932-1938

P. L. Payne British Entrepreneurship in the Nineteenth Century

G. D. Ramsay The English Woollen Industry, 1500-1750

Michael E. Rose The Relief of Poverty, 1834-1914

Michael Sanderson Education, Economic Change and Society in England 1780-1870

S. B. Saul The Myth of the Great Depression, 1873-1896

Arthur J. Taylor Laissez-faire and State Intervention in Nineteenth-century Britain

Peter Temin Causal Factors in American Economic Growth in the Nineteenth Century

Margaret Walsh The American Frontier Revisited 


\section{Enclosures in Britain 1750-1830}

Prepared for

The Economic History Society by

MICHAEL TURNER

Lecturer in Economic History

University of Hull

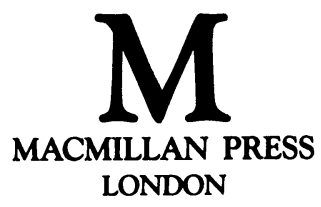


(C) The Economic History Society 1984

All rights reserved. No part of this publication may be reproduced or transmitted, in any form or by any means, without permission.

First published 1984 by

THE MACMILLAN PRESS LTD

London and Basingstoke

Companies and representatives

throughout the world

Typeset by

Wessex Typesetters Ltd

Frome, Somerset

British Library Cataloguing in Publication Data

Turner, M. E.

Enclosure in Britain, 1750-1830.-

(Studies in economic and social history)

1. Inclosures

I. Title II. Series

$33.7^{\prime} 6 \quad$ HD594.6

ISBN 978-0-333-31682-5 ISBN 978-1-349-06033-7 (eBook)

DOI 10.1007/978-1-349-06033-7 


\section{Contents}

Author's Acknowledgements and Note on References

$\begin{array}{lr}\text { Editor's Preface } & 8\end{array}$

List of Tables $\quad 9$

List of Figures $\quad 9$

1 Introduction

(i) Definition 11

(ii) Historiographical Note 12

2 Enclosure in Time and Space

(i) England 16

(ii) A Note on Wales $\quad 26$

(iii) Scotland 28

(iv) A Note on Non-Parliamentary Enclosure 33

3 Enclosure and Investment: The Decision to Enclose

(i) General Factors 36

(ii) The Open Fields: Inflexible or Adaptable? 37

(iii) Productivity Gains and Enclosure 39

(iv) Rent and Productivity Gains 41

(v) Cost-Benefit 44

(vi) Other Economic Considerations $\quad 46$

4 Investment and Cost: Part 1, The Economic Cost

(i) The Total Cost 53

(ii) Distribution of Public Costs 60 
5 Investment and Cost: Part 2, The Social Cost

(i) Social Consequences: The Background to the Debate

(ii) J. D. Chambers and Revision

(iii) Revisionism, Counter-Revised

(iv) The Recent Debates

73

(v) Enclosure and Labour Supply

6 Conclusions

81

Bibliography

84

Index

94 


\section{Acknowledgements}

MY thanks to Brenda Buchanan, Dr R. C. Allen and Dr J. Chapman for the opportunity to see their work in advance of publication. Jan Crowther and Colin Munro respectively gave me an item of information and a reference which perfectly illustrated important points in the script and for which I am grateful. Professor T. C. Smout and $\mathrm{Dr}$ I. D. Whyte gave me valuable advice in constructing the Scottish bibliography, and Professor Smout also gave me instruction about Scottish rural tenurial relationships. Derek Waite drew the maps and diagrams. I am particularly indebted to Professor Smout for his editorial guidance which transformed an excessively long first draft into a script of pamphlet size.

MICHAEL TURNER

\section{Note on References}

References in the text within square brackets refer to the numbered items in the bibliography. Colons separate italicised page numbers from their appropriate references and semicolons separate different references. 


\section{Editor's Preface}

SINCE 1968, when the Economic History Society and Macmillan published the first of the 'Studies in Economic and Social History', the series has established itself as a major teaching tool in universities, colleges and schools, and as a familiar landmark in serious bookshops throughout the country. A great deal of the credit for this must go to the wise leadership of its first editor, Professor M. W. Flinn, who retired at the end of 1977 . The books tend to be bigger now than they were originally, and inevitably more expensive; but they have continued to provide information in modest compass at a reasonable price by the standards of modern academic publications.

There is no intention of departing from the principles of the first decade. Each book aims to survey findings and discussion in an important field of economic or social history that has been the subject of recent lively debate. It is meant as an introduction for readers who are not themselves professional researchers but who want to know what the discussion is all about - students, teachers and others generally interested in the subject. The authors, rather than either taking a strongly partisan line or suppressing their own critical faculties, set out the arguments and the problems as fairly as they can, and attempt a critical summary and explanation of them from their own judgement. The discipline now embraces so wide a field in the study of the human past that it would be inappropriate for each book to follow an identical plan, but all volumes will normally contain an extensive descriptive bibliography.

The series is not meant to provide all the answers but to help readers to see the problems clearly enough to form their own conclusions. We shall never agree in history, but the discipline will be well served if we know what we are disagreeing about, and why.

University of St Andrews

T. C. SMOUT Editor 


\section{List of Tables}

I The Supply of Parliamentary Enclosure 1730-1844

II Chronology and Summary of English Parliamentary Enclosure

III Public Cost of Parliamentary Enclosure in England 1730-1844

IV Distribution of Enclosure Costs in Warwickshire and Buckinghamshire

\section{List of Figures}

1 Chronology of Parliamentary Enclosure in England 1750-1819

2 Common and Waste Enclosed as a Percentage of County Area c.1750-1870

3 The Enclosure of the Open Fields as a Percentage of County Area c. 1750-1870

4 Trends in Wheat Prices and Interest Rates 1731-1819 48-9 